DOI: 10.31866/2617-2674.4.2.2021.248772

UDC 77.03/.08:791

\title{
FEATURES OF STREET PHOTOGRAPHY AND ITS SIMILARITIES WITH CINEMATOGRAPHY
}

\author{
Serhii Bordeniuk ${ }^{1 a}$, Iryna Gavran ${ }^{2 a}$, Valeriia Hrymalska ${ }^{3 a}$ \\ ${ }^{1}$ Honorary Art Worker of Ukraine, Professor at the Film and Television Arts Department; \\ e-mail: BordenS2662@gmail.com; ORCID: 0000-0003-2561-1409 \\ ${ }^{2} \mathrm{PhD}$ in Pedagogy, Associate Professor; \\ e-mail: yarynka.77@gmail.com; ORCID: 0000-0002-6777-3038 \\ ${ }^{3}$ Master's Student at the Film and Television Arts Department; \\ e-mail: valeriiagrymalska@gmail.com; ORCID: 0000-0002-5823-7321 \\ ${ }^{a}$ Kyiv National University of Culture and Arts, Kyiv, Ukraine
}

\section{Keywords:}

photography;

cinematography;

the art of photography;

street photography;

documentary

photography;

atmospheric shot;

light;

colour;

composition;

poetic photography

\begin{abstract}
The purpose of the study is to analyze the visual features of street cinema photography and techniques for its implementation; establish the role of light colour, composition and historical features of the street genre of photography; to prove the importance of conscious departure from the established laws of photocomposition for the implementation of creative ideas. The research methodology consists in the application of the following methods: theoretical for the study and analysis of scientific publications, articles and photo albums of street photography masters; empirical - to observe and compare visual elements between cinema and photography. Scientific novelty. The detailed analysis of the main compositional methods designed to simplify the composition and analysis of the main components of a spectacular visual image that enhance the visual impact of cinematic photography on the viewer were conducted. Conclusions. The article describes in detail the visual features of creating cinematic street photography. The elements of street photography, the affinity of style with cinematography are generalized, the components for creating a strong visual effect on the audience are identified.
\end{abstract}

For citation:

Bordeniuk, S., Gavran, I. and Hrymalska, V., 2021. Features of Street Photography and Its Similarities with Cinematography. Bulletin of Kyiv National University of Culture and Arts. Series in Audiovisual Art and Production, 4(2), pp.278-285.

\section{Problem statement}

Historically, photography has been famous for its documentary and authenticity in reproducing the world around it in the smallest detail. In the course of its existence, it has borrowed a lot from traditional arts, in particular the basics of composition and some artistic and pictorial means. For its part, it also stimulated 
the ancient arts to constant rejuvenation and the search for their own, new and specific pictorial features.

The greatest influence it had on creative art, but not by cancelling its role, as some believed in the twentieth century, but on the contrary, by stimulating it to develop. 'However, in some spheres photography "added to" the art of creation, taking over its separate functions. Despite the ambiguous views in this regard, photography has established itself as an original and independent form of creativity. And, of course, the most important thing is that photography historically influenced the way of perceiving the world', as Vasilii Pylypiuk (2011, p.4), a Ukrainian documentary photographer, said in his book 'Ukrainian art Photography: stages of formation and artistic principles of development'.

With the advent of cinematography, constantly experimenting with its pictorial means, photography has adopted and positioned in the art form that is similar to it for its technical possibilities, new expressive means, fascinating colour solutions, fragmentary nature of the frame and new formats.

Modern genres of photography and its new directions are constantly investigating new ways of conveying reality, often deviating from the canons of traditional photography for obtaining desired results.

The understanding of how to break the established laws of photographic composition and photography in general, allows you to fully implement the creative idea to achieve a spectacular visual image.

\section{Recent research and publications analysis}

Despite the long-standing publication, close to 40 years since the publication date, these researches are an invariable classic for modern photographers and a valuable source of theoretical and practical information. All further investigations by other authors on these topics invariably take as their basis the books listed below, which indicates their relevance.

L. Dyko and A. Golovnya (1962) were the first to publish the theory of photographic composition and the basics of constructing an expressive image.

V. Mihalkovich and V. Stigneev (1989) investigated questions related to the concept of poetics of photography - composition, image, and photographic genres.

The optimal use of natural light and the organization of artificial light for different subjects and shooting conditions were analyzed by D. Kilpatrick (1988).

\section{Purpose of the article}

The purpose of the work is to analyze the visual features of street cinema photography; establish the role of light, colour, composition and historical features of the genre of street photography; prove the importance of consciously denying the established laws of photocomposition for the implementation of creative ideas.

\section{Main research material}

An integral part of photography (apart from its technical side) is its aesthetic category - spirituality. The peculiarity of photography is to see in the ordinary something beautiful, unusual, and most importantly - to make it a work of art. Photography is capable of spiritualizing everything: inanimate objects, nature, '... and as for the depths of the human spirit, photography, the documentary also, is capable of stunning and causing catharsis' (Pylypiuk, 2011, p.91). 
The first photos ever taken were usually taken on the streets. So, the beginning of photography was, so to speak, 'street photography'.

When analyzing street documentary photography, it is impossible not to mention the contribution to the history of the most famous master and founder of the Magnum Agency and possibly the greatest documentary photographer of Western Europe, Henri Cartier-Bresson. He rejected the idea of staged photography and refused to direct his shots. In doing so, of course, he violated the aesthetic canons espoused by other masters who imitated the art of painting.

The basic elements of a street: its complete spontaneity, detailed observation of the subjects and the willingness to show what seems important, interesting and exciting. Henri Cartier-Bresson was convinced that it is the talent of the photographer that determines the pictures of everyday life. In his opinion, a photographer should forget about everything, concentrate only on how to show reality through a simple but significant detail and manage to capture the moment at the right time. The idea was that there is a 'perfect' moment to photograph any human scene unfolding on the street. A fraction of a second before or after that golden moment, the artist believed, would greatly diminish the aesthetic value of photography.

Not always the basics of composition are sufficient for the realization of the idea, there are cases when it is the violation of these rules that leads to a satisfactory result. In her book 'Photocomposition', the director of photography, author of many famous articles, and teacher Lidiia Dyko (1962, p.155) noted that 'the artist's work on composition consists in consciously finding compositional solutions in each individual case, depending on the tasks set by the artist, and his entire creative attitude towards the world". That is why Cartier-Bresson often violated the classical laws of composition, considering that it is more valuable to convey the immediacy of the captured moment in photography than to create an ideal aesthetic picture in the general sense of artistic photography.

It must be said that cinematic photography while taking inspiration from cine$\mathrm{ma}$, has also borrowed its visual features. It is these features that give photography its cinematic appearance and therefore make cinematic photography very much akin to cinematography.

While classical photography struggles to get the exposure right, cinematographers often use a lot of shadows to give the subject shape and depth. By strategically placing your lighting tools on your subject, the artist can make beautiful images without fear of thick shadows. They may seem unpleasant at first, but if it is known how to shape them, they can be dramatic and deeply cinematic.

It is advisable to note that the construction of a cinematographic picture has its own rules and principles, combining all these meanings in the concept of 'composition in the frame'. In translation from Latin 'composition' means creation, the correlation of different parts within a frame into a unified and complete whole. The photographer uses the fundamentals of composition to reveal ideas as well as the relationship of image form to the subject because a harmonious, clear visual form will reveal the content with the necessary clarity.

When viewing a photograph, one's eyes immediately pay attention to the bright spots and follow the movement of lines in the frame. These accents are a route through the photograph for the viewer's 
eyes. It is important for the photographer to place these accents correctly to help the viewer adequately read the image and understand exactly what the author wanted to convey.

Natural lines must be used to guide the viewer's eye through the photograph to the important object. The direction and orientation of the lines play a responsible role in the construction of the frame and can evoke certain emotions and feelings. Horizontal lines - tranquillity, serenity. Vertical lines - stability, a sense of power and authority. Curved s-lines in the composition give movement, grace, liveliness. Diagonal lines evoke a sense of movement and energy and can emphasize the depth of the frame. Rising and falling diagonals are seen as lines of development and decline, a sense that the object leaves the frame and the feeling of its return.

It should be said that it is also very important to have balance in the frame. Composition is either balanced or unbalanced. Any unbalanced composition looks random, while a balanced composition looks harmonious. In her book 'Fine arts. Basics of composition', Natalia Sokolnikova (1998, p.27), Doctor of Pedagogical Sciences, author of many textbooks, noted that 'such a construction allows to achieve an impression of calmness, majesty, a special solemnity and significance of events'.

Researchers, Hanna Babenko and Nina Horuzha (2001, pp.51-52), determined in their work 'The basics of composition in fine arts' that the easiest way to balance the composition is to place the subject in the centre of the image (cinematographers often use symmetry). If you move the subject to the side, the balance is broken. One part of the picture becomes heavier and visually outweighs the other. To correct the unbalanced composition, you need to introduce some other object into the empty part of the picture.

It should be considered that in photography, weight is replaced by the volume of the DOF (Depth of Field), by colour, or by associations with heavy or light objects. The colours in which objects are coloured also have different effects on their pictorial 'weight': red and its shades are heavier than blue, bright colours are heavier than dark ones.

It is also possible to balance the figure of the model from the point of view of composition by means of all kinds of movements. According to Babenko H. V. and Horuzha N. V. (2011, p.52), if the model makes a hand gesture to one side, then compositionally it can be balanced by a leg gesture or a turn of the head to the other side. That is, a gesture to one side of any body part is counterbalanced by a gesture to the other side of the arm, leg, head or bend of the body.

One of the most amazing composition techniques that can be applied - the development of the the movement that balances the shot. This psychological effect implies a free space in the direction of movement or gaze. If you leave free space in the frame where the movement develops, the composition immediately evens out. In addition, the development of motion can be replaced by the direction of the view. However, looks are also different, and they need different free spaces in the picture. A quiet gaze needs a bit of free space. But the emotional look requires a lot more.

It is advisable to note that colour and light play an important role in the socalled visual 'language' of the picture: from the details that become expressive due to a particular light, to the viewer's sensations from objects painted in different colours. Most often, when analyzing 
the use of colour in cinema, it is appealed to the fact that colour evokes certain emotions.

For example, David Kilpatrick (1988, p.50), in his book 'Light and lighting', writes that the impression created by artistic images often depends on the 'quality' of light, the condition of the subject and weather conditions. He also notes that, in general, most people find the best scenes shot in sunlight; but for detailed reproductions, especially close-ups, overcast lighting may be the best.

Cinematic photography is more interested in lighting at sunrise and sunset. At this time, unlike in the middle of the day, the colour scheme is richer; it conveys shades from golden to bright pink.

Valentyn Mikhalkovich and Valery Stigneev (1989, p.190) noted in their work 'The poetics of photography' that 'light is capable of influencing the expressiveness of composition and, above all, the tonal perspective. On cloudy days and shortly before sunrise or after sunset the light is soft and diffused, and there are no distinct shadows. Volumes and textures of objects are expressed in a generalized manner and the depth of space is poorly perceived'.

However, the most important step in creating cinematic photography is postprocessing, which is the best way to create the specific look and feel of a movie shot. Photo post-processing uses programs such as 'Adobe Lightroom' and 'Adobe Photoshop,' which offer great potential for image transformation, where each adjustment affects the final look of the photo, from exposure correction to full image deformation.

It should be noted that the term 'exposure' refers to the amount of light hitting a light-sensitive photographic material over a certain period of time. The three main parameters affecting exposure are sensitivity, shutter speed and aperture. Most modern cameras, whether analogue or digital, automatically control these three parameters (Prophotos, 2007). However the automatic settings in cameras do not always produce satisfactory results, and the photo will require further adjustment in specially designed programs.

A feature such as 'curves' allows photographers to fine-tune their exposure. In 'Adobe Photoshop', the exposure setting adjusts all images simultaneously, but in 'Adobe Lightroom', individual settings allow more control; 'curves' adjust light, dark and mid-tone pixels individually.

Colour often plays a big role in photography - and in post-processing, too. The basic settings are brightness and saturation while adjusting individual colours offers more control. By learning to adjust individual colours, you can make hundreds of specific edits. Instead of adjusting all at once, each colour has its own individual setting, allowing you to adjust one colour while leaving all others untouched. This opens up countless possibilities, from eliminating skin redness to adjusting a photo to a specific colour scheme, which is very important for cinematic photography.

\section{Conclusions}

Beginning in 1895, when cinematography took an important place in society, it began to influence the development and practice of the still image, leading to new directions in photography with different visual features.

Cinematic photography has its own special atmosphere and mood. Cinematographers tend to focus on movement and mood modelling, the latter being by far the most important. It doesn't mat- 
ter how great your lighting is if you can't draw the audience into the story. Cinematic images are images you feel.

Mimicking the characteristics of cinematic perception of the world, street photography has begun to change, creating new visual styles. One style that is impossible not to recognize is cinematic photography. Its special feature is that it tries to resemble the frame in cinema, copying colour, frame format and spe- cific techniques of composition (such as symmetry, which is not entirely approved by the classical canons of photography). The deliberate use of composition techniques, light patterns that are appropriate to the mood of the image, colour processing that complements the atmosphere of the frame, in other words - the basic components of a spectacular image will help to increase the visual impact of the photograph on the viewer.

\section{REFERENCES}

Babenko, A.V. and Khoruzhaia, N.V., 2011. Osnovy kompozitcii v izobrazitelnom iskusstve [Fundamentals of composition in the visual arts]. Tomsk: Tomskii gosudarstvennyi universitet. Dyko, L.P. and Golovnia, A.D., 1962. Fotokompozitciia [Photocomposition]. 2nd ed. Moscow: Iskusstvo.

Kilpatrik, D., 1988. Svet $i$ osveshchenie [Light and Lighting]. Translation from English by S.F. Kostromina. Moscow: Mir.

Mikhalkovich, V.I. and Stigneev, V.T., 1989. Poetika foto [Poetics of photography]. Moscow: Iskusstvo.

Pylypiuk, V.V., 2011. Ukrainska khudozhnia fotohrafiia etapy stanovlennia ta mystetski zasady rozvytku [Ukrainian art photography stages of formation and artistic principles of development]. Lviv: Svit.

Sokolnikova, N.M., 1988. Izobrazitelnoe iskusstvo [Fine arts]. Obninsk: Titul Ekspozitciia v fotografii: chto eto takoe [Exposition in photography: what is it], 2007. Prophotos, [online] 25 November 2007. Available at: <https://prophotos.ru/lessons/3114-ekspozitsiyadlya-nachinayuschih> [Accessed 09 November 2020]. 


\title{
ОСОБЛИВОСТІ ВУЛИЧНОЇ ФОТОГРАФІЇ ТА ÏI СПОРІДНЕНІСТЬ 3 КІНЕМАТОГРАФОМ
}

\author{
Сергій Борденюк ${ }^{1 a}$, Ірина Гавран ${ }^{2 a}$ Валерія Гримальська ${ }^{3 a}$ \\ ${ }^{1}$ заслужений діяч мистецтв України, професор кафедри кіно-, телемистецтва; \\ e-mail: bordens2662@gmail.com; ORCID: 0000-0003-2561-1409 \\ ${ }^{2}$ кандидат педагогічних наук, доцент; \\ e-mail: yarynka.77@gmail.com; ORCID: 0000-0002-6777-3038 \\ ${ }^{3}$ магістрант кафедри кіно-, телемистецтва; \\ e-mail: valeriiagrymalska@gmail.com; ORCID: 0000-0002-5823-7321

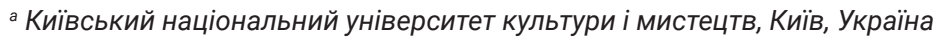

\section{Анотація}

Мета дослідження - проаналізувати візуальні особливості вуличної кінематографічної фотографії та техніки їі реалізації; встановити роль світла, кольору, композиції та історичних особливостей вуличного жанру фотографії; довести важливість усвідомленого відходу від усталених законів фотокомпозиції за для реалізації творчого задуму. Методологія дослідження полягає у застосуванні таких методів: теоретичного - для вивчення та аналізу наукових видань, статей та фотографічних альбомів майстрів вуличної фотографії; емпіричного - для спостереження та порівняння візуальних елементів між кінематографом та фотографією. Наукова новизна: проведено детальний аналіз основних композиційних методів, створених для спрощення композиції, та розбір основних складових ефектного візуального зображення, що посилюють візуальний вплив кінематографічної фотографії на глядача. Висновки. У статті детально описані візуальні особливості створення кінематографічної вуличної фотографії. Узагальнено елементи вуличної фотографії, простежено спорідненість стилю з кінематографом, визначено складові для створення сильного візуального ефекту на аудиторію.

Ключові слова: фотографія; кінематограф; фотомистецтво; вулична фотографія; документальна фотографія; атмосферний знімок; світло; колір; композиція; поетична фотографія 


\title{
ОСОБЕННОСТИ УЛИЧНОЙ ФОТОГРАФИИ И ЕЕ РОДСТВО С КИНЕМАТОГРАФОМ
}

\author{
Сергей Борденюк ${ }^{1 a}$, Ирина Гавран ${ }^{2 a}$, Валерия Гримальская ${ }^{3 a}$ \\ 1 заслуженный деятель искусств Украины, профессор кафедры кино-, телеискусства; \\ e-mail: BordenS2662@gmail.com; ORCID: 0000-0003-2561-1409 \\ ${ }^{2}$ кандидат педагогических наук, доцент; \\ e-mail: yarynka.77@gmail.com; ORCID:0000-0002-6777-3038 \\ ${ }^{3}$ магистрант кафедры кино-, телеискусства; \\ e-mail: valeriiagrymalska@gmail.com; ORCID: 0000-0002-5823-7321 \\ а Киевский национальный университет культуры и искусств, Киев, Украина
}

\begin{abstract}
Аннотация
Цель исследования - проанализировать визуальные особенности уличной кинематографической фотографии и техники ее реализации; установить роль света, цвета, композиции и исторических особенностей уличного жанра фотографии; доказать важность осознанного ухода от устоявшихся законов фотокомпозиции для реализации творческого замысла. Методология исследования заключается в применении таких методов: теоретического - для изучения и анализа научных изданий, статей и фотографических альбомов мастеров уличной фотографии; эмпирического - для наблюдения и сравнения визуальных элементов между кинематографом и фотографией. Научная новизна: проведен детальный анализ основных композиционных методов, предназначенных для упрощения композиции, и разбор основных составляющих эффектного визуального изображения, усиливающих визуальное воздействие кинематографической фотографии на зрителя. Выводы. В статье подробно описаны визуальные особенности кинематографической уличной фотографии. Обобщены элементы уличной фотографии, прослежено родство стиля с кинематографом, определены составляющие для создания сильного визуального эффекта на аудиторию.
\end{abstract}

Ключевые слова: фотография; кинематограф; фотоискусство; уличная фотография; документальная фотография; атмосферный снимок; свет; цвет; композиция; поэтическая фотография 